\title{
Formononetin Production by Large-Scale Cell Suspension Cultures of Medicago sativa $\mathbf{L}$.
}

\author{
Tayfun Aktas ${ }^{\circledR 1}$, Hatice Colgecen ${ }^{1}$, Havva Karahan ${ }^{1, *}$
}

${ }^{1}$ Department of Biology, Faculty of Arts and Sciences, Zonguldak Bülent Ecevit University, Zonguldak, Turkey

\begin{abstract}
In this study, calli of Medicago sativa L. cv. Elçi (alfalfa Elçi) were inoculated in cell suspension culture and analyzed for aggregate assay, cell viability test, total phenolic content assay, DPPH free radical scavenging activity and formononetin assay by means of High-Performance Liquid Chromatography (HPLC). Hypocotyl, cotyledon and apical meristem explants were taken from 15-day-old aseptic seedlings and germinated in MS medium. $10 \mathrm{~g}$ calli were grown for each explant and then transferred into cell suspension culture. The highest cell viability rate, which was $75 \%$, and the highest DPPH free radical scavenging activity with $51.36 \%$ was measured in $1000 \mathrm{~mL}$ cell suspension culture, while the highest total phenolic content, i.e. $40.2 \mathrm{mg} / \mathrm{g}$, was quantified in $250 \mathrm{~mL}$ cell suspension culture. In accordance with the findings of the study, the production of formononetin was higher in the calli derived from cell suspension cultures than in herb samples of $M$. sativa. Moreover, in $1000 \mathrm{~mL}$ cell suspension culture, $4.99 \mathrm{mg} / \mathrm{g}$ of formononetin concentration was quantified, which scored the highest. In large-scale cell suspension cultures of M. sativa, it was possible to increase the production of formononetin production. Hence, due to its medicinal significance, a method has been tested to obtain higher amounts of this compound.
\end{abstract}

\section{ARTICLE HISTORY}

Received: April 23, 2020

Revised: September 21, 2020

Accepted: January 19, 2021

\section{KEYWORDS}

Cell viability test, DPPH,

Formononetin, Medicago sativa, Total phenols

\section{INTRODUCTION}

Medicago sativa L. (alfalfa) is an important feed plant in all over the world with its ability to adapt to different climates and its high feed efficiency and quality. M. sativa spreads in world's temperate regions (such as the USA, Southern Canada, Europe, China, South America and South Africa). In general, it shows spreading characteristics up to $2400 \mathrm{~m}$. It is more resistant to drought compared to other feed types.

The plant has been used as a herbal supplement for increasing strength and energy, detoxifying blood, fighting against infections and treating anemia. Medicago is also known as a model plant because of its ability to regenerate in vitro in plant tissue culture (Erişen, 2006). $M$. sativa is also reported to reduce the menopausal symptoms in women by increasing the levels of estrogen (Gülen, 2013; Çölgeçen et al., 2014; Franciscis et al., 2019). M. sativa is rich in flavonoids, too. The term "flavonoids" is derived from the Latin word "flavus," meaning yellow. The basic flavonoid structure consists of 15 carbon atoms $\left(\mathrm{C}_{6}-\mathrm{C}_{3}-\mathrm{C}_{6}\right.$ system) and 2phenyl benzopyrone (diphenylpropane). Additionally, flavonoids are polyphenolic compounds

CONTACT: Havva Karahan $\square$ havva01030@hotmail.com Department of Biology, Faculty of Arts and Sciences, Zonguldak Bülent Ecevit University, Zonguldak, Turkey 
(Kahraman et al., 2002). They are found in all organs of the plants such as flower, leaf, root, stem, seed and fruit (Iş1k, 2005). Although the flavonoids have been studied for many years, their biological activities and cellular mechanisms have not yet been fully elucidated. However, studies have shown that they have free radical-scavenging (antioxidant) effect, cardiovascular and liver protective role, antiviral, and as recently suggested, anticancer properties (Birman, 2012).

Analyzed in this study, formononetin is an isoflavonoid. Clinical trials have shown that isoflavonoids reduce menopausal symptoms by increasing estrogen levels. It is also known that Asian women are less likely to have estrogen-dependent cancers due to high soybean-based nutrient intake with isoflavonoid content. Formononetin inhibits tumor growth and is antiallergic (Evcimen \& Aslan, 2015; Franciscis et al., 2019, Tay et al., 2019). From this research, it was aimed to inoculate M. sativa calli in cell suspension culture. Also, it was analyzed for aggregate assay, cell viability test, total phenolic content assay, DPPH free radical scavenging activity and formononetin assay by means of HPLC.

\section{MATERIAL and METHODS}

\subsection{Plant Material}

$M$. sativa was grown in the trial garden of Department of Biology of Bülent Ecevit University. Two different herb samples were collected from the trial garden in May and September. The samples with an average size of $40-50 \mathrm{~cm}$ were dried in a lyophilizer and stored at $-80^{\circ} \mathrm{C}$.

\subsection{Aseptic Seedling Plant}

The seeds were sterilized in $96 \%$ ethanol for one minute and then transferred to $10 \%$ commercial sodium hypochlorite solution for 5 minutes. Then, they were rinsed 3 times in autoclaved distilled water and germinated in hormone-free Murashige and Skoog (MS) medium (Murashige \& Skoog, 1962). Hypocotyl, cotyledon and apical meristem explants were taken from 15-day-old aseptic seedlings, and later calli were grown.

\subsection{In vitro Culture Medium}

Standard MS medium was used as the callus culture medium. $1.5 \mathrm{mg} / \mathrm{L}$ Kinetin, $1.5 \mathrm{mg} / \mathrm{L}$ NAA, $0.7 \mathrm{mg} / \mathrm{L}$ 2,4-D were added to MS medium as plant growth regulators. All MS media were autoclaved for sterilization with $20 \mathrm{~g} / \mathrm{L}$ sucrose and $7 \mathrm{~g} / \mathrm{L}$ agar. Agar-free MS medium + $1.5 \mathrm{mg} / \mathrm{L}$ Kinetin, $1.5 \mathrm{mg} / \mathrm{L} \mathrm{NAA}, 0.7 \mathrm{mg} / \mathrm{L} \mathrm{2,4} \mathrm{D,} 20 \mathrm{~g} / \mathrm{L}$ sucrose were used for cell suspension cultures. Hypocotyl, cotyledon and apical meristem explants from the 15 days-old aseptic seedlings were germinated in MS medium as 5 explants on each petri dish (Figure 1). The calli were subcultured in every three weeks, and they were stored in the dark at $24 \pm 2{ }^{\circ} \mathrm{C}$. Adequately matured friable calli were grown in cell suspension cultures in 4 different volumes $(2.5 \mathrm{~g} / 100 \mathrm{~mL}, 6.25 \mathrm{~g} / 250 \mathrm{~mL}, 12.5 \mathrm{~g} / 500 \mathrm{~mL}$ and $25 \mathrm{~g} / 1000 \mathrm{~mL})$. The calli that was transferred to the cell suspension cultures were shaken at $180 \mathrm{rpm}$ on the shaker for 20 days. The experiment was repeated 3 times.

\subsection{Cell Viability}

The calli were shaken for 20 days on the shaker and then filtered with a 200 mesh SigmaAldrich Cell Dissociation Kit for $1 \mathrm{~min}$. The filtered cells were then transferred to microcentrifuge tubes, stained with $0.5 \mathrm{~mL}$ of $0.2 \%$. Trypan Blue for 20 minutes and then washed with pure distilled water. The washed cells were placed on the microscope slide and covered with cover slips. Cell count was performed by Olympus BX51 Microscope and Olympus SC100 Camera, and Digimizer Image Analysis Software was used for image 
processing (Figure 2). Percent viability was calculated by this formula: $\%$ viability $=($ live cell count / total cell count) x 100 (Patel et al., 2009).

Figure 1. Matured calli A) hypocotyl, B) cotyledon, C) apical meristem.

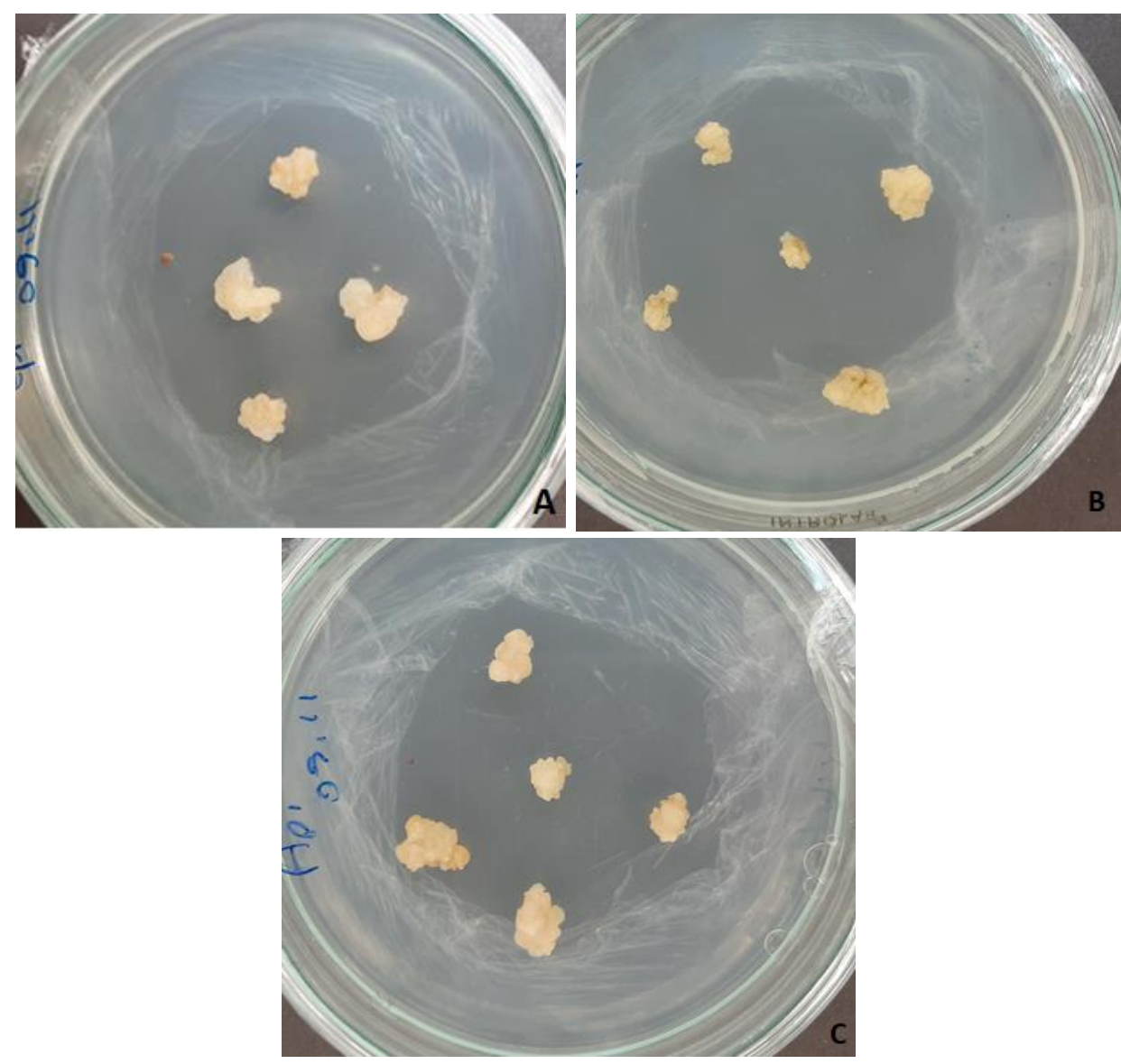

\subsection{Extraction}

Lyophilized samples were pulverized for extraction. $1 \mathrm{~g}$ of each sample was used. They were shaken on the shaker with $100 \mathrm{~mL}$ of $80 \% \mathrm{MeOH}$ at $180 \mathrm{rpm}$, then filtered. The remaining extract was shaken with $150 \mathrm{~mL}$ of $80 \% \mathrm{MeOH}$ on a shaker at $180 \mathrm{rpm}$ for 24 hours and filtered with filter paper. After filtration, $80 \%$ of $\mathrm{MeOH}$ was evaporated in a water bath at $45^{\circ} \mathrm{C}$ in the rotary evaporator. After evaporation, the remaining extract was dissolved with $10 \mathrm{~mL}$ of $99.9 \%$ $\mathrm{MeOH}$.

\subsection{Total Phenolic Content Assay}

Total phenolic content was determined according to the Folin-Ciocaltaeu method (Wang \& Lee, 1996; Ismail et al., 2010; Karimi et al., 2013). The samples were prepared as $1 \mathrm{mg} / \mathrm{mL}$. Each sample $(20 \mu \mathrm{L})$ was reacted with $100 \mu \mathrm{L}$ of Folin-Ciocalteu reagent. Sodium carbonate $(20 \% \mathrm{w} / \mathrm{v})$ for $300 \mu \mathrm{L}$, and $1580 \mu \mathrm{L}$ distilled water were then added. The mixture was incubated at room temperature for $30 \mathrm{~min}$. Each reaction was replicated 3 times. The absorbance of each reaction was determined at $765 \mathrm{~nm}$ by VWR V-1200 Spectrophotometer. Gallic acid (15.62 $\mathrm{mg} / \mathrm{L}, 31.75 \mathrm{mg} / \mathrm{L}, 62.5 \mathrm{mg} / \mathrm{L}, 125 \mathrm{mg} / \mathrm{L}, 250 \mathrm{mg} / \mathrm{L}, 500 \mathrm{mg} / \mathrm{L}$ and $1000 \mathrm{mg} / \mathrm{mL}$ ) was used as a positive control.

\subsection{DPPH Free Radical Scavenging Activity Assay}

DPPH free radical scavenging activity was measured using the Sanchez-Moreno method (Sanchez-Moreno et al.,1998,1999 ${ }^{\mathrm{a}}, 1999^{\mathrm{b}}$ ). The samples were prepared as $1 \mathrm{mg} / \mathrm{mL}, 0.5$ 
$\mathrm{mg} / \mathrm{mL}, 0.25 \mathrm{mg} / \mathrm{mL}, 0.125 \mathrm{mg} / \mathrm{mL}$. For comparative purposes, Ascorbic Acid, Butyl hydroxy toluene (BHT), Butyl hydroxy anisole (BHA) solutions were also prepared as $1 \mathrm{mg} / \mathrm{mL}, 0.5$ $\mathrm{mg} / \mathrm{mL}, 0.25 \mathrm{mg} / \mathrm{mL}, 0.125 \mathrm{mg} / \mathrm{mL}$. The absorbances of the samples were read at $517 \mathrm{~nm}$ by V-1200 Spectrophotometer including 4 cuvettes. Percentage inhibition was calculated with this formula (1):

$$
\% \text { inhibition }=\frac{\mathrm{Ab}(\text { control })-\mathrm{Ab}(\text { sample })}{\mathrm{Ab}(\text { control })} \times 100
$$

\subsection{HPLC-UV Analyses}

Formononetin standard was prepared as 300 ppm, 150 ppm, 75 ppm, 37.5 ppm, 18.75 ppm, $9.37 \mathrm{ppm}$, and $4.68 \mathrm{ppm}$ dissolved $99.9 \% \mathrm{MeOH}$. The formononetin of the M. sativa extracts was identified on a Shimadzu 1200 HPLC chromatographic system. Separation was performed using a column $(\mathrm{C} 185 \mu \mathrm{m} 250 \times 4.6 \mathrm{~mm})$. The samples were run in $70 \% \mathrm{MeOH}$ with a flow rate of $0.35 \mathrm{~mL} / \mathrm{min}$ and injection volume of $20 \mu \mathrm{L}$. The maximum absorbance of the HPLC was set at $254 \mathrm{~nm}$. Formononetin was monitored in the scheduled multiple reaction monitoring mode (Rodrigues et al., 2014; Krakowska et al., 2018).

\subsection{Statistical Analyses}

SPSS 13 (SPSS Inc., Chicago, IL, USA) (Snedecor \& Cochran, 1967) and Microsoft Office 2010 Excel Software were used in viable cell count, total phenolic content assay, DPPH free radical scavenging activity assay and HPLC quantification. $p<0.05$ was considered statistically significant.

\section{RESULTS and DISCUSSION}

In the present study, MS3 medium was used as the most successful of previously tested media (Çölgeçen et al., 2014). Çölgeçen et al. (2014), had used hypocotyl, cotyledon, apical meristem, epicotyl and young primary leaf explants taken from seedlings. Due to the low callus growth rate observed in epicotyl and young primary leaf explants, trials were carried out with hypocotyl, cotyledon and apical meristem explants in the study. The rate of contamination in callus and suspension culture media has decreased down to 5\% due to use of UV-C lamps in the laboratory. There was no problem in callus production and suspension cultures.

\subsection{Aggregate Measurement Results}

Friable callus was used in cell suspension cultures. Although calli were distributed in the suspension cultures, their distribution was not homogeneous. Prior to filtration in cell suspension culture media, photographs were taken and aggregate length was measured, yet no significant differences were observed. Generally, aggregates were about $5 \mathrm{~mm}$. The lowest aggregation size was $3 \mathrm{~mm}$ and the highest was $7.4 \mathrm{~mm}$ (Table 1).

As callus darkening started after the $21^{\text {st }}$ day, 21-day-old yellow friable calli were taken into an agar-free MS media for large-scale cell suspensions of $100 \mathrm{~mL}, 250 \mathrm{~mL}, 500 \mathrm{~mL}, 1000$ $\mathrm{mL}$. Callus cells were left in the shaker in the suspension media and stained with $0.2 \%$ Trypan Blue for viability assays. In their study on M. sativa L. cv. Chaubet, Steward et al. (1999), used $0.375 \%$ Trypan Blue for cell viability assays. They followed the viability of cells for 11 days and found that the best result of $80 \%$ was achieved on the first day. Cell viability displayed a decreasing trend and dropped to $20 \%$ by the end of the $11^{\text {th }}$ day. As the viability in the cells could not be detected at high concentrations of Trypan Blue, $0.2 \%$ of it was used in this study. Cell count was made for 20-day-old suspensions and thus the cell viability was determined. There was no significant difference in cell viability among $100 \mathrm{~mL}, 250 \mathrm{~mL}, 500 \mathrm{~mL}$ and 1000 $\mathrm{mL}$ cell suspension cultures. However, the highest cell viability of $75 \%$ was obtained in the 
$1000 \mathrm{~mL}$ culture. The lowest cell viability of $62.40 \%$ was quantified in $500 \mathrm{~mL}$ culture, which could be attributed to the lack of cell homogeneity.

Table 1. Aggregate measurement results $(\mathrm{mm})(p<0.05)$.

\begin{tabular}{cc}
\hline Extract & Result $(\mathrm{mm})$ \\
\hline $100 \mathrm{~mL}$ & $4.67 \pm 0.1$ \\
$250 \mathrm{~mL}$ & $5.18 \pm 0.08$ \\
$500 \mathrm{~mL}$ & $4.95 \pm 0.09$ \\
$1000 \mathrm{~mL}$ & $5.81 \pm 0.06$ \\
\hline
\end{tabular}

\subsection{Cell Viability Measurement Results}

In cell viability analyses, the best result was obtained as $75 \%$ in $1000 \mathrm{~mL}$ cell suspension cultures. Percentage viability was calculated as $71.40 \%$ in the $100 \mathrm{~mL}, 67.80 \%$ in $250 \mathrm{~mL}$ and $62.40 \%$ in $500 \mathrm{~mL}$ cell suspension cultures (Table 2).

Table 2. Percentage viability $(\%)(p<0.05)$.

\begin{tabular}{cc}
\hline Extract & Percentage viability (\%) \\
\hline $100 \mathrm{~mL}$ & $71.40 \pm 4.1$ \\
$250 \mathrm{~mL}$ & $67.80 \pm 2.2$ \\
$500 \mathrm{~mL}$ & $62.40 \pm 1.8$ \\
$1000 \mathrm{~mL}$ & $75.00 \pm 0.9$ \\
\hline
\end{tabular}

\subsection{Total Phenolic Compound Measurement Results}

Comparing May and September herb samples, the best result for total phenolic content was obtained as $44.2 \mathrm{mg} / \mathrm{g}$ in the September one. Total phenolic content was measured as 32.2 $\mathrm{mg} / \mathrm{g}$ in the May sample. In cell suspension cultures, $250 \mathrm{~mL}$ sample gave the best result for total phenolic content with $40.2 \mathrm{mg} / \mathrm{g}$. The $100 \mathrm{~mL}$ cell suspension culture had the lowest amount of total phenolic compounds (Table 3).

Table 3. Cell suspension cultures, total phenolic contents in May and September herb samples $(p<0.05)$.

\begin{tabular}{cc}
\hline Extract & Total phenolic content $(\mathrm{mg} / \mathrm{g})$ \\
\hline $100 \mathrm{~mL}$ & $30.2 \pm 0.4$ \\
$250 \mathrm{~mL}$ & $40.2 \pm 0.3$ \\
$500 \mathrm{~mL}$ & $32.2 \pm 0.3$ \\
$1000 \mathrm{~mL}$ & $34.2 \pm 0.2$ \\
May herb sample & $32.2 \pm 0.5$ \\
September herb sample & $44.2 \pm 0.1$ \\
\hline
\end{tabular}

\subsection{Total Phenolic Compound Measurement Results}

DPPH free radical scavenging activity of May and September herb samples was higher than that of cell suspension cultures. Although there was no significant difference among the cell suspension cultures, the best result of $51.36 \%$ was obtained in the $1000 \mathrm{~mL}$ one (Table 4). 
Figure 2. Stained cells A) $100 \mathrm{~mL}$, B) $250 \mathrm{~mL}$, C) $500 \mathrm{~mL}$, D) $1000 \mathrm{~mL}$ cell suspension cultures.
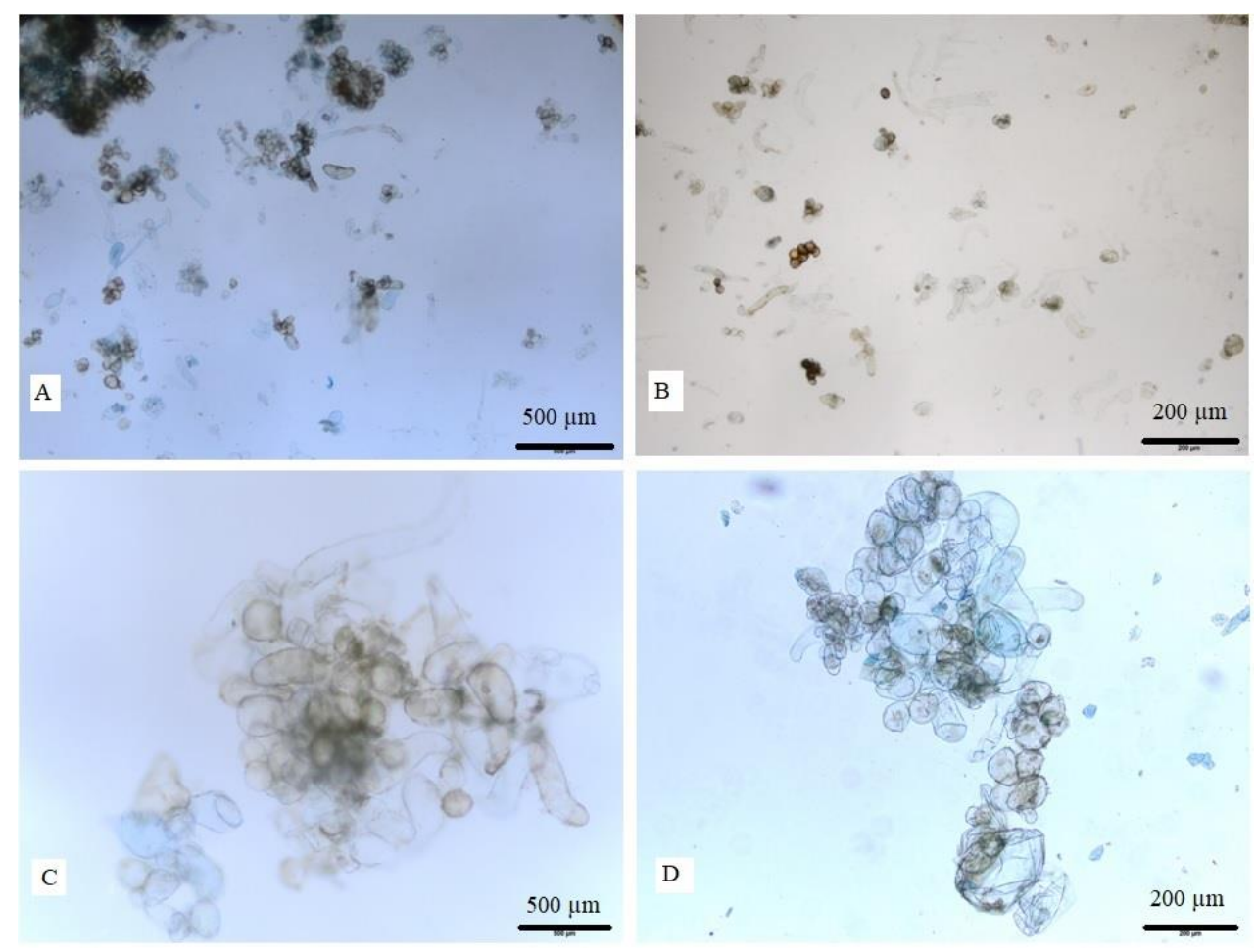

Table 4. DPPH free radical scavenging activity results $(\%)(p<0.05)$.

\begin{tabular}{cc}
\hline Extract & DPPH scavenging activity (\%) \\
\hline $100 \mathrm{~mL}$ & $41.63 \pm 3.1$ \\
$250 \mathrm{~mL}$ & $45.22 \pm 1.1$ \\
$500 \mathrm{~mL}$ & $47.26 \pm 1.3$ \\
$1000 \mathrm{~mL}$ & $51.36 \pm 1.2$ \\
May herb sample & $80.51 \pm 2.5$ \\
September herb sample & $85.69 \pm 2.1$ \\
Ascorbic acid & $97.83 \pm 0.9$ \\
BHT & $95.24 \pm 0.9$ \\
BHA & $95.29 \pm 1.1$ \\
\hline
\end{tabular}

Antioxidants are radical scavenging compounds used in the treatment of various diseases. High antioxidant capacity in plants is an indication that the plant has medicinal importance. Bora and Sharma (2010), reported that $M$. sativa Linn. has $71.05 \%$ DPPH scavenging activity. Karimi et al. (2013), analyzed dry leaf samples of $M$. sativa (provided from a Taghavi farm in Iran) and quantified the total phenolic content as $45.2 \mathrm{mg} / \mathrm{g}$ and DPPH scavenging activity as 54\%. Zinca and Vizireanu (2013), evaluated 2, 3, 4, 5, 6 and 7-day-old $M$. sativa L. seedlings (provided from a health store in Canada) for their total phenolic content and antioxidant activity. The highest total phenolic content $(0.9 \mathrm{mg} / 100 \mathrm{~g})$ was measured in 4-day-old seedling and the highest antioxidant activity (64\%) was shown by 6-day-old seedling. Silva et al. (2013), analyzed $M$. sativa L. (provided from market) herb samples and reported $56 \%$ DPPH scavenging activity. Different from these researchers, in this study, $M$. sativa L. herb samples were collected separately in May and September. These samples were compared according to their total phenolic content and DPPH scavenging activity. The highest total phenolic content 
(44.2 $\mathrm{mg} / \mathrm{g}$ ) and the highest DPPH scavenging activity $(85.69 \%)$ was observed in the September herb sample.

\subsection{HPLC-UV Measurement Results}

The calli derived from large-scale cell suspension cultures of $M$. sativa L. cv. Elçi (alfalfa Elçi) and the herb samples collected in May and September were analyzed by HPLC-UV method. The retention time for formononetin was 16 mins (Figure 3). Of the herb samples, May sample had the highest formononetin content with $2.07 \mathrm{mg} / \mathrm{g}$, while of the cell suspension cultures, $1000 \mathrm{~mL}$ has shown the highest formononetin concentration of $4.99 \mathrm{mg} / \mathrm{g}$. Additionally, formononetin content increased in cell suspension cultures compared to naturally occurring M. sativa L. cv. Elçi (Alfalfa Elçi) herbs (Table 5).

Table 5. HPLC-UV analysis results (Formononetin) $(\mathrm{mg} / \mathrm{g})(p<0.05)$.

\begin{tabular}{cc}
\hline Extract & Quantity $(\mathrm{mg} / \mathrm{g})$ \\
\hline $100 \mathrm{~mL}$ & $3.72 \pm 0.04$ \\
$250 \mathrm{~mL}$ & $3.46 \pm 0.06$ \\
$500 \mathrm{~mL}$ & $3.36 \pm 0.08$ \\
$1000 \mathrm{~mL}$ & $4.99 \pm 0.09$ \\
May herb sample & $2.07 \pm 0.05$ \\
September herb sample & $1.84 \pm 0.09$ \\
\hline
\end{tabular}

Figure 3. Chromatogram of $1000 \mathrm{~mL}$ cell suspension culture.

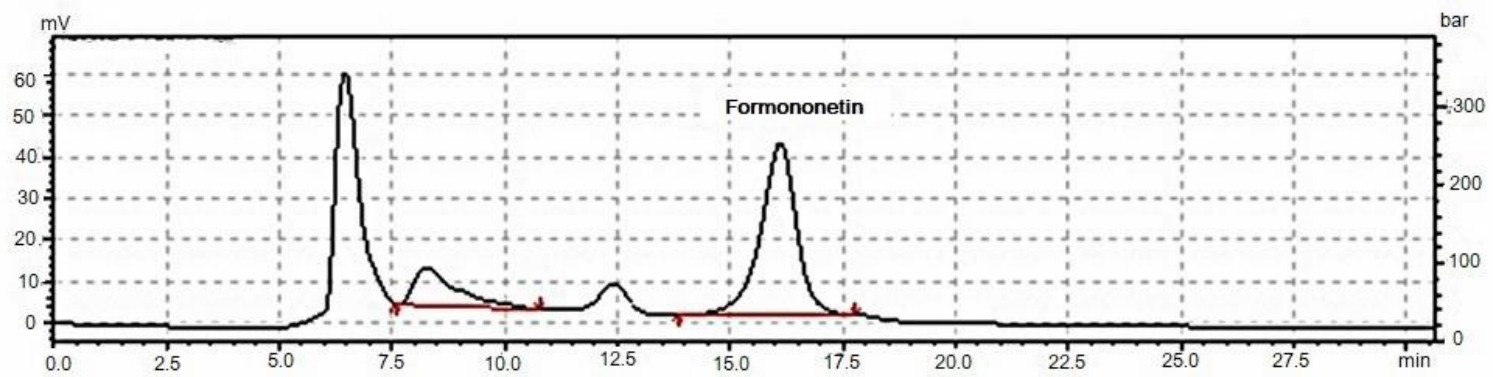

M. sativa $\mathrm{L}$. is a valuable medicinal plant which is rich in flavonoid compounds. The levels of these compounds increase in response to various factors. For example, elicitor trials may increase the amount of these compounds. M. sativa L. cv. Moapa 69 had been exposed to Rhizobium meliloti bacteria (Dakora et al., 1993). No formononetin was detected in the control group yet it was detected in the treatment group subjected to Rhizobium meliloti bacteria, but it could not be quantified. $M$. sativa $\mathrm{cv}$. Nagyszenas was subjected to to different concentrations of potassium nitrate $\left(\mathrm{KNO}_{3}\right)$ and its formononetin content was determined by HPLC analysis (Coronado et al., 1995). Formononetin content was lower than $1 \mathrm{mg}$. The data suggested that low concentrations of $\mathrm{KNO}_{3}$ increased formononetin content compared to high concentrations. Although no elicitor trials were conducted in the present study, formononetin was determined in herb sample and the quantity was 2,5 times higher.

Culture media are also important to increase flavonoid production. SH (Shenk and Hildebrandt) callus and suspension culture media was prepared for M. sativa cv. Apollo (He et al., 1998). The scale of cell suspension culture media was $50 \mathrm{~mL}$. The researchers revealed formononetin content during HPLC analyses of calli, but the amount of formononetin was not measured. Tetrahydrofuran and distilled pure water were used as solvent for HPLC analysis. No formononetin content could be observed in M. sativa L. cv. Elçi (alfalfa Elçi) herb samples, 
yet they revealed formononetin production in cell suspension cultures (Çölgeçen et al., 2014). Formononetin content was measured as $0.32 \mathrm{mg} / 100 \mathrm{mg}$ in $100 \mathrm{~mL}$ suspension cultures. In this study, MS medium was used both for callus and suspension culture. Herb samples were found to contain formononetin. The highest formononetin content of $4.99 \mathrm{mg} / \mathrm{g}$ was found in 1000 $\mathrm{mL}$ cell suspension cultures while the lowest of $0.37 \mathrm{mg} / \mathrm{g}$ was found in $100 \mathrm{~mL}$ cell suspension cultures.

The use of different solvents or different chromatographic methods may result in varying flavonoid contents. A quantitative analysis had been conducted on some flavonoids in $M$. sativa cv. Lucerne (Martin et al., 2006). $260 \mathrm{~nm}$ wavelength was used in LC-MS analysis for this quantification of flavonoids in herb samples. Formononetin content was measured as $40 \mathrm{mg} / \mathrm{kg}$. The herb samples of M. sativa cv. Azurara and 6 different Medicago species were evaluated for their flavonoid content (Rodrigues et al., 2014). HPLC analysis was performed with the columns C18 $150 \mathrm{~mm}$ x $4.60 \mathrm{~mm}$. M. sativa extracts prepared with aqueous and ethanol solutions were compared. No formononetine and daidzein could be detected in the M. sativa extract that was prepared with aqueous solution, while $2.40 \mathrm{mg} / \mathrm{kg}$ formononetine was quantified in the M. sativa extract that was prepared with ethanol extract. In this study, analyses were performed by HPLC at a $254 \mathrm{~nm}$ wavelength with C18 4,6 x $250 \mathrm{~mm}$ columns. $70 \%$ $\mathrm{MeOH}$-distilled pure water was used as solvent. The highest formononetin content was measured as $4.99 \mathrm{mg} / \mathrm{g}$. As a remarkable finding, this study indicated that herp samples of $M$. sativa L. cv. Elçi collected in May $(2.07 \mathrm{mg} / \mathrm{g})$ and those collected in September $(1.84 \mathrm{mg} / \mathrm{g})$ contain different amounts of formononetin. It was clearly revealed that seasonal changes have significant effect on formononetin content in plants.

\section{CONCLUSION}

Clinical trials have shown that formononetin reduces the symptoms of menopause by increasing estrogen levels. Thus, the extracts of $M$. sativa with high content of formononetin can be a starting point for the development of new pharmacotherapies. Hence, a method has been tested to increase the production of this compound with such high medicinal value. In this study, formononetin production was increased in large-scale cell suspension cultures of $M$. sativa L. cv. Elçi (Alfalfa Elçi). Future studies should focus on the development and application of modern sample preparation techniques, and better cell suspension culture methods should be developed for the production of formononetin in M. sativa. Meanwhile, the development of advanced methods for purifying special and biologically active compounds will enable our future understanding of their actions on organisms. Also, this study provides a basis for achieving high-efficiency production with bioreactors and can be investigated in further studies.

\section{Declaration of Conflicting Interests and Ethics}

The authors declare no conflict of interest. This research study complies with research publishing ethics. The scientific and legal responsibility for manuscripts published in IJSM belongs to the author(s).

\section{Authorship contribution statement}

Tayfun Aktaş: Investigation, Resources, Visualization and Writing -original draft. Hatice Çölgeçen: Methodology, Supervision, and Validation. Havva Karahan: Investigation, Resources, Visualization and Corresponding.

\section{Orcid}

Tayfun Aktas (D) https://orcid.org/0000-0001-5253-1354

Hatice Colgecen (D) https://orcid.org/0000-0001-8246-4279

Havva Karahan (D) https://orcid.org/0000-0003-0518-6265 


\section{REFERENCES}

Birman, H. (2012). Bioactivities of plant flavonoids and the possible action mechanisms. Journal of Istanbul Faculty of Medicine, 75, 3.

Bora, K.S. \& Sharma, A. (2010). In Vitro Antioxidant and Free Radical Scavenging Potential of Medicago sativa Linn. J Pharm Res., 3(6), 1206-1210.

Coronado, C., Angelo, J., Zuanazzi, S., Sallaud, C., Quirion, J.C., Esnault, R., Husson, H.P., Kondorosi, A. \& Ratet, P. (1995). Alfalfa Root Flavonoid Production 1s Nitrogen Regulated. Plant Physiol., 108, 533-542.

Çölgeçen, H., Koca, U.Ç., Kartal, M., \& Büyükkartal, H.N. (2014). Comprehensive evaluation of phytoestrogen accumulation in plants and in vitro cultures of Medicago sativa L. 'Elçi' and natural tetraploid Trifolium pratense L. Turkish Jour of Bio., 38, 619-627. https://doi.org/10.3906/biy-1310-17

Dakora, F.D., Joseph, C.M., \& Phillips, D.A. (1993). Alfalfa (Medicago sativa L.) root exudates contain isoflavonoids in the presence of Rhizobium meliloti. Plant Physiol., 101, 819-824.

Erişen, S. (2006). Plant Regeneration Through Somatic Embryogenesis in Alfalfa (Medicago sativa L.). Journal of Agricultural Sciences, 11(3), 311-315. https://doi.org/10.1501/Tari mbil_0000000570

Evcimen, M. \& Aslan, R. (2015). Physiological Effects of Commonly Used Medicinal and Aromatic Plant's Antioxidant Phytochemicals. Kocatepe Veterinary Journal, 8(2), 65-78. https://doi.org/02199320009640

Franciscis, P., Colacurci, N., Riemma, G., Conte, A., Pittana, E., Guida, M., \& Schiattarella, A.A. (2019). A Nutraceutical Approach to Menopausal Complaints. Medicina (Kaunas), 55(9), 544. https://doi.org/10.3390/medicina55090544

Gülen, S. (2013). In vitro Antioxidant Properties of Vine and Clover leaves. [Master's thesis, Trakya University], Edirne, Turkey.

He, X.Z., Reddy, J.T., \& Dixon, R.A. (1998). Stress responses in alfalfa (Medicago sativa L.) Cdna cloning and characterization of an elicitor inducible isoflavone 7-Omethyltransferase. Plant Mol. Bio., 36, 43-54. https://doi.org/10.1023/A:1005938121453

Ismail, H.I., Chan, K.W., Mariod, A.A. \& Ismail, M. (2010). Phenolic content and antioxidant activity of cantaloupe (Cucumis melo) methanolic extracts. Food Chem., 119(2), 643-647. https://doi.org/10.1016/j.foodchem.2009.07.023

Işık, F.E. (2005). Phytochemical investigation of Trifolium resopinatum L. var. microcephalum plant grows in Edirne zone. [Doctoral Thesis, Trakya University], Edirne, Turkey.

Kahraman, A., Serteser, M., \& Köken, T. (2002). Flavonoids. The Medical Journal of Kocatepe, $3,1-8$.

Karimi, E., Oskoueian, E., Oskoueian, A., Omidvar, V., Hendra, R., \& Nazeran, H. (2013). Insight Into the Functional and Medicinal Properties of Medicago sativa (Alfalfa) Leaves Extract. J Med Plant Res., 7(7), 290-297. https://doi.org/10.5897/JMPR11.1663

Krakowska, A., Rafińska, K., Walczak, J. \& Buszewski, B. (2018). Enzyme-assisted optimized supercritical fluid extraction to improve Medicago sativa polyphenolics isolation. Industrial Crops and Products, 124, 931-940. https://doi.org/10.1016/j.indcrop.2018.08. 004

Martin, L.M., Castilho, M.C., Silveira, M.I., \& Abreu, J.M. (2006). Liquid Chromatographic Validation of a Quantitation Method for Phytoestrogens, Biochanin-A, Coumestrol, Daidzein, Formononetin, and Genistein, in Lucerne. J Liq Chromatogr R T., 29, 28752884. https://doi.org/10.1080/10826070600961076

Murashige, T., \& Skoog, F. (1962). A revised medium for rapid growth and bioassay with tobacco tissue cultures. Physiol Plantarum, 15, 473-497. https://doi.org/10.1111/j.13993054.1962.tb08052.x 
Patel, S., Gheewala, N., Suthar, A., \& Shah, A. (2009). In-Vitro Cytotoxicity Activity of Solanum nigrum Extract Against Hela Cell Line and Vero Cell Line. Int J Pharm., 1(1).

Rodrigues, F., Almeida, I., Sarmento, B., Amaral. M.H. \& Oliveira, M.B.P.P. (2014). Study of the isoflavone content of different extracts of Medicago spp. as potential active ingredient. Industrial Crops and Products, 57, 110-115.

https://doi.org/10.1016/j.indcrop.2014.03.014

Sanchez-Moreno, C., Larrauri, J.A., \& Saura-Calixto, F. (1998). A procedure to measure the antiradical efficiency of polyphenols. $J$ Sci Food Agri., 79, 270-276. https://doi.org/10.1002/(SICI)1097-0010(199802)76:2<270::AID-JSFA945>3.0.CO;2-9

Sanchez-Moreno, C., Larrauri, J.A., \& Saura-Calixto, F. $\left(1999^{\mathrm{a}}\right)$. Free radical scavenging capacityand inhibition of wines, grape juices and related polyphenolic constituents. Food Res Int. 32, 407-412. https://doi.org/10.1016/S0963-9969(99)00097-6

Sanchez-Moreno, C., Larrauri, J.A., \& Saura-Calixto, F. $\left(1999^{\mathrm{b}}\right)$. Free radical scavenging capacity of selected red, rose and white wines. J Sci Food Agri., 79, 1301-1304. https://doi.org/10.1002/(SICI)1097-0010(19990715)79:10<1301::AIDJSFA367>3.0.CO;2-Y

Silva, L.R., Pereira, M.J., Azevedo, J., Gonçalves, R.F., Valentão, P., Guedes de Pinho, P., \& Andrade, P.B. (2013). Glycine max (L.) Merr., Vigna radiata L. and Medicago sativa L. sprouts: A natural source of bioactive compounds. Food Res Int., 50. 167-175.

Snedecor, G.W., \& Cochran, W.G. (1967). In: Snedecor GW, Cochran WG, editors. Statistical methods, 6th ed. USA: Iowa State University Press, pp. 327-329.

Steward, N., Martin, R., Engasser, J.M., \& Goergen, J.L. (1999). A new methodology for plant cell viability assessment using intracellular esterase activity. Plant Cell Rep., 19. 171-176, https://doi.org/10.1007/s002990050729

Tay, K.C., Tan, L.H., Chan, C.K., Hong, S.L., Chan, K.G., Yap, W.H., Pusparajah, P., \& Lee, L.H., Goh, B.H. (2019). Formononetin: A Review of Its Anticancer Potentials and Mechanisms. Front Pharmacol., 10, 820. https://doi.org/10.3389/fphar.2019.00820

Wang, C.K., \& Lee, W.H. (1996). Separation, Characteristics, and Biological Activities of Phenolics in Areca Fruit. J Agric Food Chem., 44, 2014-2019. https://doi.org/10.1021/jf 9506110

Zincă, G., \& Vizireanu, C. (2013). Impact of germination on phenolic compounds content and antioxidant activity of alfalfa seeds (Medicago sativa L.). J Agroaliment Processes Technol., 19(1), 105-110. 